matter, which are readily removed by the mechanica action of percolating rain-water. In such naturally-formed gullets run the feeders of water that are met with in sinking through the magnesian limestone, and these feeders, by chemical action, must cause much additional destruction of the rock. Quite apart from the water which runs off into the sea, that which is pumped up annually by the local water company is estimated to contain lime and magnesia in solution corresponding to nearly forty cubic yards of solid rock.

It seems evident that masses of rock must from time to time fall from the roofs of channels so formed. But we are not here left entirely to conjecture, for, at numerous points along the Durham coast, sections of such channels are exposed that are entirely filled up by angular fragments of the very rock which forms the cliff, and bound together by a cement of the same material. The "breccia-gashes," as they have been termed by Prof. Lebour, vary in width from a few feet to many yards; they are almost invariably narrow at the bottom, and generally wide at the top. "In some cases the broken fragments within the fissures can be traced graduating through semi-brecciated portions of beds to wholly undisturbed strata in the walls or fissure-cheeks. When the top of a fissure is exposed in section, the breccia is also seen usually to pass gradually upwards, first into semi-brecciated matter, and finally to undisturbed or only slightly synclinal beds bridging over the mass of broken rock. When the entire transverse section of a fissure is exposed, it is seen to be a deep V-shaped ravine or gullet, tapering to a point below, and the rocks below it are wholly undisturbed" (p. r66).

Tests.--Individual spurious earthquakes belonging to this class are the most troublesome of all to investigate, for, in most cases, we have to rely on circumstantial evidence alone. The principal tests will be obvious from the above descriptions. They are: (I) the small disturbed area and the comparatively great intensity near its centre; (2) the nature of the shock and sound; (3) the known or inferred honeycombed structure of the district, and the occurrence at other times of subsidences at the surface.

Charles Davison.

\section{REPORT OF THE LONDON TECHNICAL EDUCATION BOARD.}

THE annual report of the Technical Education Board of the London County Council was recently presented to the Council. The following paragraphs of the report, referring to the Board's relations with the Department of Science and Art and with the new London University, are abridged from the Technical Education Gazette.

\section{Relations zvith the Department of Science and Art.}

The Council has been recognised by the Department of Science and Art as the local authority responsible for science and art instruction within the area of the County of London in accordance with Clause VII. of the Science and Art Directory. The powers and duties which such recognition may give have been delegated by the Council to the Board in the same way as the powers conferred by the Technical Instruction Acts were delegated. Ever since the passing of the Technical Instruction Act in 1889 , the Science and Art Department has been in the position of the central authority for technical instruction, and the county councils and county borough councils have been in the position of local authorities for technical instruction. Clause VII. introduced a certain readjustment of duties as between the central authority and the local authorities. No new powers are conferred outside the provisions of the Technical Instruction Acts, but the clause provides for some of the functions under those Acts which have hitherto been discharged by the central authority being delegated to the local authority. Over thirty counties and county boroughs have availed themselves of the clause, and it is stated by those who have had experience of the working of the new system that it is advantageous both to particular schools and to the district generally.

The principal benefits which the Board anticipates from the working of Clause VII, in London are the following :-

(a) Increased facilities for coordinating and organising science and art work in accordance with the particular needs of each locality.

(b) Greater regularity and promptitude in the payment of the grants earned on the Department's examinations.

NO. I 545 , VOL. 60$]$ (c) Increased opportunities for urging upon the Department such modifications in their courses of instruction as may be specially required by the circumstances of London schools and institutions.

The Technical Instruction Act of I 889 affords, perhaps, the first legislative example in educational work of adaptation to special local requirements. In the definition of technical in struction the Act includes " any other form of instruction (in. cluding modern languages and commercial and agricultural subjects), which nay for the time being be sanctioned by that Department [the Department of Science and Art] by a minute laid before Parliament and made on the representation of a local authority that such a form of instruction is required by the circumstances of its district." The Technical Instruction Act having provided for the creation of powerful and disinterested authorities for the conduct and supervision of technical in struction over large areas, Parliament, in the words quoted above, expressed its willingness to give to these authorities an important part in determining the particular field of education which should come within their influence, thus enabling both the matter and the manner of education to be adapted to local needs, It is reasonable to suppose that the same principle will now apply in connection with the subjects of technical instruction which are defined by detailed syllabuses in the Science and Art Directory. The Department has already expressed its willingness to meet the wishes of the local authorities in respect of several administrative details.

The New University of London.

In order to formulate the Board's views with regard to the new University, a special sub-committee was last year established for the purpose of investigating the whole subject and reporting to the Board as to the steps which might be deemed necessary for making representations to the Commissioners on any points in which the Board might be specially interested. In pursuance of this policy, the Board forwarded to the Commissioners an expression of its views upon certain matters. In particular, the Board urged upon the Commissioners the desirability of recognising separate faculties for engineering and for economic and commercial science. The Board's representations were supported by similar expressions of opinion from other quarters, and the Commissioners have come to the decision to adopt the policy which the Board favoured. In the draft statutes which they have prepared for the new University, they have decided to provide for $(a)$ a special faculty of engineering, and $(b)$ a special faculty of economics and political science (including commerce and industry). There is little doubt that the establishment of these faculties will give considerable encouragement to the technical and commercial work in which the Board is specially interested. Recognising the importance of developing the higher departments of these branches of study, the Board has undertaken to allocate to the University out of the funds from time to time placed at its disposal by the Council an annual sum of 2500 ? towards the maintenance of the faculty of engineering in the new University, and a further sum of $2500 l$. towards the maintenance of the faculty of economics and political science (including commerce and industry), on condition that satisfactory arrangements are made in the constitution of the University with regard to evening students, and the recognition and admission to the several faculties of duly qualified teachers in the polytechnics.

\section{UNIVERSITY AND EDUCATIONAL INTELLIGENCE.}

OXFord. - The following is the speech delivered by the Public Orator, Dr. W. W. Merry, on the occasion of his presenting Dr. R. Trimen, F.R.S., for the honorary M.A. degree on May I6:Praesento vobis Ronaldum Trimen, Societatis Regiae Socium, nuper autem Societatis Entornologicae apud Londinium Praesidem. Vir insignis, qui notitiam suam officiosissime impertiendo de Universitate Oxoniensi optime meruit, diu in Africa aus. trali est commoratus, non utique ut gemmas et aurum fodinis erueret neque ut cum Batavis litem sereret, sed ut Naturae arcana altius scrutaretur ac praesertim insectorum inexploratas consuetudines patefaceret.

"In tenui labor, at tenuis non gloria."

Quotus enim quisque mirum illud ingenium quo Natura inermes bestiolas instruxerit vel diligentius investigavit vel exposuit 
luculentius? Quis clarius iliustravit raram sollertiam qua minuta animalium genera, vel ut compares alliciant vel ut infestas hostium incursiones arceant, nunc colores mutare, nunc novum aliquod simulacrum assumere, nunc etiam sexum mentiri videantur? Quae quidem omnia si primo visu parvi momenti esse habeantur, eadem, nisi magnopere fallor, oculis subjecta fidelibus et summa accuratione tractata, immane quantum prosunt ad intimas vitae leges enodandas. Quae cum ita sint, haud dubitarem eruditissimi auctoris C. Plinii Secundi verba citare de insectorum corporibus scribentis: "In his tam parvis atque tam nullis quanta vis, quae ratio, quam inextricabilis perfectio !... Sed turrigeros elephantorum miramur humeros, taurorumque colla et truces in sublime jactus, tigrium rapinas, leonum jubas, cum rerum natura nusquam magis quam in minimis tota sit; et in contemplatione naturae nihil possit videri supervacuum."

Praesento vobis ornatum et excultum virum Ronaldum Trimen, qui et ipse "Naturalis Historiae Libris" tam laudabile incrementum addidit, ut admittatur ad gradum Magistri in facultate Artium, honoris causa.

CAMirridge. - Mr. W. Chawner, Master of Emmanuel College, is to be Vice-Chancellor during the ensuing academical year.

Mr. R. C. Punnett, of Caius College, has been nominated to occupy the University table at the Marine Biological Laboratory at Plymouth.

The Chemical, Pathological, and Anatomical Laboratories will be open during the ensuing Long Vacation, and a number of special courses of instruction will be given in July and August.

The electors to the new chair of Agriculture are the Right Hon. W. H. Long, Mr. A. E. Shipley, Dr. D. MacAlister, Prof. Liveing, Sir J. H. Gilbert, Prof. Foster, Prof. Marshall Ward, and Sir Walter Giltey.

IT is satisfactory to know that the value of scientific education and research in agriculture is becoming more and more recognised by foremost agriculturists. Mr. Boyd-Kinnear refers to these matters in a contribution to the Morning Post, and to the lack of interest taken in them by British farmers. He points out that a knowledge of the scientific principles of agriculture is of fundamental importance, and that what should be taught in our schools are the sciences on which farming rests-physics, chemistry, mechanics, and the physiology of plants and animals. The sound remark is made that for a farmer to work without this kind of knowledge, is much the same as if a doctor were educated by being shown cases in a hospital before he had learned anything of anatomy or the nature of drugs. In order to know agriculture, it is necessary to understand first of all the elements and the action of the soil and the air, and the operations of life. But all that the most learned in science know of these things is infinitely small compared with the amount that is yet unknown. There is, therefore, urgent need, not only for teaching what is known, but also for learning more. That is, we ought to have both schools where the fundamental sciences which agriculture involves are taught, and also institutions for further research into the secrets yet undiscovered.

Referring to agricultural research stations, Mr. Boyd-Kinnear remarks :- In all countries but England these are provided and liberally maintained by the State. In Germany there are, and have been for the last half-century, no fewer than sixty-seven agricultural teaching and research stations. France has fiftythree, Austria thirty-five, and even Russia has fourteen. The other European States, including countries which we call so backward as Spain and Portugal, have sixty-one among them. The United States have fifty-four, these being supported by the individual States; Canada has several, while Brazil, Japan, and Java have each one! England has-none! none, that is, with State endowment. During the last few years, the County Councils of Sussex, Yorkshire, Bucks, and Durham have established teaching colleges, but without any adequate provision for research. There are also the privately-conducted colleges of Cirencester, Downton, and one or two others, while the halfcentury of inquiries conducted by Sir John Lawes is deserving of grateful acknowledgment. But isolated and private effort is wholly inadequate to meet the want, or even to direct public attention to it.

NO. I 545, VOL. 60]

\section{SOCIETIES AND ACADEMIES. LONDON.}

Royal Society, May 4.- " An Observation on Inheritance in Parthenogenesis." By Ernest Warren, D.Sc., University College, London. Communicated by W. F. R. Weldon, F.R.S.

If the hypotheses of Weismann on heredity and variation be founded on fact, then it should follow that offspring produced by parthenogenesis should exhibit little or no departure from their parthenogenetic mother.

It appeared an easy investigation to test this supposition by direct measurement. For this purpose, Daphnia magna (Straus) was chosen.

On twenty-three Daphnia, the following measurements were made : ( $r$ ) the length of the protopodite of the second antenna of the right side ( $C \mathrm{D}$ see Fig.), and (2) the total length of the body $(\mathrm{A} B)$. The first dimension was expressed in thousandths of the second, because these animals (like very many invertebrates) continue to grow throughout life. The broods, amounting in all to ninety-six young, produced by the twenty-three mothers (themselves originating by parthenogenesis), were similarly measured.

The children of the same parthenogenetic family were now seen to vary considerably. A correlation table between the mothers and offspring was prepared, and from it the coefficient of correlation was found to be 466 . The standard deviation (S.D.) of an array of offspring was 5.22 thousandths of the body length : if we express it as a kind of coefficient of variation we have $\frac{\text { S.D. of array }}{\text { Mean of all the offspring }} \times 100=3.06$. 